\title{
Comparative Analysis of Type III Secreted Effector Genes Reflects Divergence of Acidovorax citrulli Strains into Three Distinct Lineages
}

\author{
Noam Eckshtain-Levi, Tamar Munitz, Marija Živanović, Sy M. Traore, Cathrin Spröer, Bingyu Zhao, \\ Gregory Welbaum, Ron Walcott, Johannes Sikorski, and Saul Burdman
}

First, second, and tenth authors: Department of Plant Pathology and Microbiology and the Otto Warburg Center for Agricultural Biotechnology, The Robert H. Smith Faculty of Agriculture, Food and Environment, The Hebrew University of Jerusalem, Rehovot, Israel; third and eighth authors: Department of Plant Pathology, The University of Georgia, Athens; fourth, sixth, and seventh authors: Department of Horticulture, Virginia Polytechnic Institute, Blacksburg; and fifth and ninth authors: Leibniz Institute DSMZ-German Collection of Microorganisms and Cell Cultures (DSMZ), Braunschweig, Germany.

Accepted for publication 12 May 2014.

\begin{abstract}
Eckshtain-Levi, N., Munitz, T., Živanović, M., Traore, S. M., Spröer, C., Zhao, B., Welbaum, G., Walcott, R., Sikorski, J., and Burdman, S. 2014. Comparative analysis of type III secreted effector genes reflects divergence of Acidovorax citrulli strains into three distinct lineages. Phytopathology 104:1152-1162.

Acidovorax citrulli causes bacterial fruit blotch of cucurbits, a serious economic threat to watermelon (Citrullus lanatus) and melon (Cucumis melo) production worldwide. Based on genetic and biochemical traits, $A$. citrulli strains have been divided into two distinct groups: group I strains have been mainly isolated from various non-watermelon hosts, while group II strains have been generally isolated from and are highly virulent on watermelon. The pathogen depends on a functional type III secretion system for pathogenicity. Annotation of the genome of the group II strain AAC00-1 revealed 11 genes encoding putative type III secreted (T3S)

effectors. Due to the crucial role of type III secretion for A. citrulli pathogenicity, we hypothesized that group I and II strains differ in their T3S effector repertoire. Comparative analysis of the 11 effector genes from a collection of $22 \mathrm{~A}$. citrulli strains confirmed this hypothesis. Moreover, this analysis led to the identification of a third A. citrulli group, which was supported by DNA:DNA hybridization, DNA fingerprinting, multilocus sequence analysis of conserved genes, and virulence assays. The effector genes assessed in this study are homologous to effectors from other plant-pathogenic bacteria, mainly belonging to Xanthomonas spp. and Ralstonia solanacearum. Analyses of the effective number of codons and gas chromatography content of effector genes relative to a representative set of housekeeping genes support the idea that these effector genes were acquired by lateral gene transfer. Further investigation is required to identify new T3S effectors of $A$. citrulli and to determine their contribution to virulence and host preferential association.
\end{abstract}

Bacterial fruit blotch (BFB) of cucurbits is caused by the gramnegative, seedborne bacterium Acidovorax citrulli (formerly $A$. avenae subsp. citrulli) $(30,42)$. This disease gained importance after the occurrence of devastating outbreaks in watermelon fields in the United States during the late 1980s $(4,20,30,32)$. Since then, the pathogen has spread worldwide and to other hosts in the cucurbit family such as melon, squash, pumpkin, and cucumber (1). To date, there is no reliable source of disease resistance to this highly destructive pathogen, and chemical control has limited efficacy for disease management (4). Therefore, A. citrulli represents a serious threat to the cucurbit industry, primarily to watermelon and melon production $(4,21)$. Despite the economic importance of $\mathrm{BFB}$, little is known about basic aspects of $A$. citrulli pathogenicity and factors that influence host-pathogen interactions.

A. citrulli strains can be divided into at least two welldifferentiated groups: group I strains are generally moderately to highly virulent on non-watermelon plants (mainly melon), whereas group II strains have been mainly isolated from and are highly virulent to watermelon plants. Group II strains are weakly to moderately virulent on other cucurbits (28). This distinction is

Corresponding author: S. Burdman; E-mail address: saul.burdman@mail.huji.ac.il

* The $\boldsymbol{e}$-Xtra logo stands for "electronic extra" and indicates that the online version contains one supplemental appendix, seven supplemental figures, and three supplemental tables.

http://dx.doi.org/10.1094/PHYTO-12-13-0350-R

(C) 2014 The American Phytopathological Society clearly supported by a variety of DNA fingerprinting techniques, including pulsed-field gel electrophoresis (PFGE) and repetitive polymerase chain reaction (rep-PCR), carbon utilization profiles, and fatty acid methyl ester (FAME) analysis by gas chromatography (GC) $(3,38,39)$.

Many gram-negative plant-pathogenic bacteria utilize a functional type III secretion system (T3SS) for pathogenicity and hypersensitive response (HR) induction in susceptible and resistant plants, respectively. The genes encoding the components of the type III secretion apparatus are named hypersensitive response and pathogenicity ( $h r p$ ) genes and are located in large (generally 20- to $25-\mathrm{kb}$ ) clusters (5). Similarly, A. citrulli strains possess hrp gene clusters, and mutagenesis analyses revealed that A. citrulli requires a functional T3SS to infect cucurbit plants and to elicit an HR in incompatible tomato and tobacco plants $(1,17)$. Pathogenic bacteria utilize the T3SS to secrete effector proteins into the plant cell. Although no reports about functional characterization of $A$. citrulli effectors have been published to date, studies with many type III secreted (T3S) effectors from several plant-pathogenic bacteria have revealed that most contribute to suppress plant defense responses and to manipulate the host cell metabolism to benefit the pathogen $(27,45)$.

The sequencing and annotation of the genome of the A. citrulli group II strain AAC00-1 by the Joint Genome Institute (GenBank NC_008752) revealed the presence of at least 11 genes encoding putative T3S effectors, based on their homology to other plantpathogenic bacterial genes. Due to the demonstrated role of effectors in host-pathogen interactions, we hypothesize that differences in the arsenal of T3S effector genes between group I and II 
strains of A. citrulli may play a role in determining preferential association of the pathogen with different cucurbits.

In the present study, we performed an extensive comparative sequence analysis of the aforementioned $11 \mathrm{~T} 3 \mathrm{~S}$ effector genes using a set of $22 \mathrm{~A}$. citrulli strains. This set included group I and II strains isolated from different cucurbit hosts and from various geographical locations. Here, we show that the effector sequences exhibited low codon usage bias and scatter GC content compared with a large set of housekeeping genes, which implies lateral gene transfer (LGT) as the mechanism responsible for the acquisition of T3S effector genes by A. citrulli. Phylogenetic analyses of the assessed effector gene sequences revealed that the strains clustered into two distinct groups that concurred with the established groups I and II. Interestingly, two strains, ZUM4000 and ZUM4001 (hereafter, ZUM strains), were shown to belong to a distinct clade. In addition, DNA from these strains yielded distinguishable rep-PCR profiles and were consistently less virulent than group I and II strains on watermelon, melon, and squash seedlings. DNA:DNA hybridization assays confirmed that the ZUM strains belong to the $A$. citrulli species. Altogether, the data presented here support the existence of a third group of pathogenic $A$. citrulli strains.

\section{MATERIALS AND METHODS}

Bacterial strains. A. citrulli strains used for sequencing of T3S effector genes and other assays are listed in Table 1 . The $A$. citrulli type strain DSM17060 (American Type Culture Collection 29625) (42) was used as reference for DNA:DNA hybridization. A. citrulli strains were generally grown in nutrient broth (NB) (Difco, Franklin Lakes, NJ) or nutrient agar (NA; NB containing agar at $15 \mathrm{~g} /$ liter) at $28^{\circ} \mathrm{C}$, unless stated otherwise. Escherichia coli DH5 $\alpha$ (12) was used for cloning and sequencing. This strain was grown in lysogeny broth (LB) broth (Difco) or LB agar (LB containing agar at $15 \mathrm{~g} /$ liter) at $37^{\circ} \mathrm{C}$.

Cloning and sequencing of effector genes. The predicted open reading frame (ORF) for each putative T3S effector was amplified by PCR with primers that were designed based on the AAC00-1 genome sequence (GenBank NC_008752). PCR primers used in this study are listed in Supplemental Table 1. ORFs of effector genes were PCR amplified, cloned, and sequenced using primers corresponding to the predicted start and stop of translation regions. To allow reliable sequencing of the entire ORF, some of the cloned fragments were also sequenced with internal primers. When PCR products could not be obtained for some strains, new PCR primers corresponding to regions from outside or inside of the coding sequences were designed. PCR was performed in an Eppendorf (Hamburg, Germany) Thermal Cycler using REDTaq ready mix (Sigma-Aldrich, St. Louis, MO) in 50- $\mu$ reaction volumes, according to the manufacturers' instructions. The PCR thermal profile consisted of an initial denaturation for $5 \mathrm{~min}$ at $95^{\circ} \mathrm{C}$, followed by 35 cycles of denaturation for $30 \mathrm{~s}$ at $95^{\circ} \mathrm{C}$, annealing for $40 \mathrm{~s}$ at $\mathrm{X}^{\circ} \mathrm{C}$, and elongation at $72^{\circ} \mathrm{C}$ for $\mathrm{Y}$ seconds $(\mathrm{X}$ and $\mathrm{Y}=$ annealing tem-

TABLE 1. List of Acidovorax citrulli strains used in this study and distribution of the 11 putative T3S effector genes and the housekeeping gene gltA in these strains

\begin{tabular}{|c|c|c|c|c|c|c|c|c|c|c|c|c|}
\hline \multirow[b]{2}{*}{ Group } & \multirow[b]{2}{*}{ Strain } & \multirow[b]{2}{*}{ Country } & \multirow[b]{2}{*}{ Year $^{\mathrm{a}}$} & \multirow[b]{2}{*}{ Host } & \multirow[b]{2}{*}{ Haplotype $^{b}$} & \multicolumn{6}{|c|}{ Effector gene (Aave gene number) $^{\mathrm{c}}$} & \multirow[b]{2}{*}{ gltA } \\
\hline & & & & & & $\begin{array}{l}0277 \\
1548 \\
2173 \\
2876 \\
3452 \\
3462\end{array}$ & 2166 & 2708 & 3062 & 3237 & 4728 & \\
\hline I & $\mathrm{M} 1^{\mathrm{d}}$ & Israel & 2000 & Melon & $\mathrm{B} 21$ & $\checkmark$ & 8 & $x$ & $s<$ & $\checkmark$ & $\checkmark$ & $\checkmark$ \\
\hline I & Tw76 & Taiwan & $1995-1999$ & Melon & $\mathrm{B} 13(\mathrm{Y})$ & $\checkmark$ & 8 & $x$ & 8 & $\checkmark$ & $\checkmark$ & $\checkmark$ \\
\hline I & AAC $98-17^{\mathrm{g}}$ & United States & 1999 & Pumpkin & $\mathrm{B} 6(\mathrm{~N})$ & $\checkmark$ & 8 & $x$ & $8<$ & $\checkmark$ & $\checkmark$ & $\checkmark$ \\
\hline I & AAC $203-57^{\mathrm{h}}$ & Honduras & 2003 & Watermelon & B9 (R) & $\checkmark$ & $s<$ & $x$ & $s<$ & $\checkmark$ & $\checkmark$ & $\checkmark$ \\
\hline I & AACAU- $9^{i}$ & Australia & 1999 & Melon & B5 (M) & $\checkmark$ & 8 & $x$ & se & $\checkmark$ & $\checkmark$ & $\checkmark$ \\
\hline III & ZUM4000j & India & 2008 & Watermelon & nd & $\checkmark$ & $x$ & $x$ & $\checkmark$ & $x$ & $8<$ & $\checkmark$ \\
\hline III & ZUM4001 ${ }^{\mathrm{j}}$ & India & 2008 & Watermelon & nd & $\checkmark$ & $x$ & $x$ & $\checkmark$ & $x$ & $8<$ & $\checkmark$ \\
\hline II & $7 \mathrm{a} 1^{\mathrm{e}}$ & Israel & 1995 & Watermelon & A23 & $\checkmark$ & $\checkmark$ & $\checkmark$ & $\checkmark$ & $\checkmark$ & $\checkmark$ & $\checkmark$ \\
\hline II & Tw16 & Taiwan & 1995-1999 & Watermelon & A6 (G) & $\checkmark$ & $\checkmark$ & $\checkmark$ & $\checkmark$ & $\checkmark$ & $\checkmark$ & $\checkmark$ \\
\hline II & Tw148f & Taiwan & 1995-1999 & Watermelon & A6 (G) & $\checkmark$ & $\checkmark$ & $\checkmark$ & $\checkmark$ & $\checkmark$ & $\checkmark$ & $\checkmark$ \\
\hline II & AAC $92-17^{g+i}$ & United States & 1992 & Watermelon & A4 (D) & $\checkmark$ & $\checkmark$ & $\checkmark$ & $\checkmark$ & $\checkmark$ & $\checkmark$ & $\checkmark$ \\
\hline II & AAC94-12 & United States & 1994 & Watermelon & $\mathrm{A} 11(\mathrm{~W})$ & $\checkmark$ & $\checkmark$ & $\checkmark$ & $\checkmark$ & $\checkmark$ & $\checkmark$ & $\checkmark$ \\
\hline II & AAC $94-21^{\mathrm{g}}$ & United States & 1994 & Watermelon & $\mathrm{A} 3(\mathrm{C})$ & $\checkmark$ & $\checkmark$ & $\checkmark$ & $\checkmark$ & $\checkmark$ & $\checkmark$ & $\checkmark$ \\
\hline II & AAC206-102k & China & 2000 & Melon & A13 & $\checkmark$ & $\checkmark$ & $\checkmark$ & $\checkmark$ & $\checkmark$ & $\checkmark$ & $\checkmark$ \\
\hline
\end{tabular}

a Haplotypes based on pulsed-field gel electrophoresis analyses. Letters in parenthesis represent previously reported haplotypes $(38,39)$ while letter/number combinations represent 10 current haplotype designations; nd = nondetermined.

${ }^{\mathrm{b}}$ Names of genes are according to the annotation of the sequenced strain AAC00-1: $\checkmark=$ the gene is present in an intact form; $\boldsymbol{x}=$ the gene could not be detected; and $\mathcal{S}=$ the gene is present but has base deletions causing frame shifts relative to strain AAC00-1.

c Year of isolation. For the strains isolated in Taiwan, there is not a record of the exact year of isolation.

${ }^{\mathrm{d}}$ Source of bacterial strain: Burdman et al. (3).

e Source of bacterial strain: Isaac Assouline.

f Source of bacterial strain: Hsiou-Chen Huang.

g Source of bacterial strain: Walcott et al. (39).

${ }^{\text {h }}$ Source of bacterial strain: Ron Walcott.

${ }^{\text {i }}$ Source of bacterial strain: Walcott et al. (38).

j Source of bacterial strain: Bert Woudt.

${ }^{k}$ Source of bacterial strain: Feng et al. (10). 
peratures and elongation times are detailed in Supplemental Table 2). A final extension step was performed at $72^{\circ} \mathrm{C}$ for $10 \mathrm{~min}$. PCR products were cloned into plasmid pTZ57R/T (Fermentas, Burlington, Canada) using the InsTAclone kit (Fermentas). Plasmids were sequenced at Hy Labs (Rehovot, Israel) and data were analyzed using the ContigExpress software (Invitrogen, Carlsbad, CA). In all cases, the ORFs were completely sequenced from both strands and mismatches were rechecked by additional, independent PCR reactions and sequencing.

Phylogenetic and single-nucleotide polymorphism analyses. Full effector sequences (both amino acid and nucleotide) were aligned using the BioEdit software (Ibis Biosciences, Carlsbad, CA). Phylogenetic trees were generated by three different methods-maximum parsimony, maximum likelihood, and neighbor-joining — using MEGA5 software (34). Bootstrap values were derived from 1,000 replicates in each case to validate tree topology. Phylogenetic trees were generated for individual ORFs of effector genes as well as for concatenated sequences of all effector ORFs. The genetic dissimilarity of A. citrulli effector genes to their closest homologous sequences in the database was too large $(>21 \%)$ to use the latter as suitable outgroups (31). Therefore, artificial outgroups were created by randomly generating nucleotide substitutions in strain AAC00-1 at a rate of 2 to $3 \%$ in positions conserved among the different strains (31). Phylogenetic trees were generated in a similar manner based on multilocus sequence analysis (MLSA) of seven housekeeping genes-gltA, $\operatorname{trpB}$, lepA, ugpB, gmc, phaC, and pilT-of strain ZUM4000 (for which we have the draft genome sequence) and selected group I and II strains, whose sequences are available from the study of Feng et al. (10). In this case, outgroups consisted of ortholog sequences from the closely related A. avenae 30003, as reported by Feng et al. (10). Sequence polymorphism, GC content, and effective number of codons (ENC) were determined using DnaSP software (24).

Seedling virulence assays. Virulence of $A$. citrulli strains representative of each group (I, II, and ZUM strains) was evaluated on watermelon (Citrullus lanatus), melon (Cucumis melo), and squash (Cucurbita pepo) seedlings, as previously described $(14,38)$. Briefly, 'Crimson Sweet' watermelon, 'Athena' melon (cantaloupe type), and 'Early Yellow Crookneck' squash seedlings were grown in $250-\mathrm{ml}$ plastic pots in a greenhouse $\left(30\right.$ to $35^{\circ} \mathrm{C}$, $\approx 80 \%$ relative humidity ( $\mathrm{RH}$ ), and $\approx 12 \mathrm{~h}$ of natural sunlight daily). Seedlings were cultivated in a 3:1 ratio of fine-grade composted pine bark and vermiculite. Two weeks after planting, seedlings were spray-inoculated with cell suspensions of $\approx 1 \times 10^{6} \mathrm{CFU} / \mathrm{ml}$ of group I (M6, Tw76, AAC98-17, AAC203-57, and AACAU-9, 5), group II (AAC00-1, Tw16, Tw148, AAC94-21, AAC206-102, and 7a1), and ZUM (ZUM4000 and ZUM4001) strains. To prepare bacterial suspensions, $-80^{\circ} \mathrm{C}$ freezer stock cultures of each strain were cultured on King's B medium (18) at $28^{\circ} \mathrm{C}$ for $48 \mathrm{~h}$. Subsequently, a single colony of each culture was used to inoculate $3 \mathrm{ml}$ of $\mathrm{NB}$, which was allowed to grow at $30^{\circ} \mathrm{C}$ for $12 \mathrm{~h}$ with agitation at $250 \mathrm{rpm}$ in an incubator shaker (Innova, New Brunswick, NJ). Cells in $1 \mathrm{ml}$ of each NB culture were pelleted by centrifugation at $10,000 \times g$ for $2 \mathrm{~min}$, rinsed once with $0.1 \mathrm{M}$ phosphate buffered saline (PBS), and resuspended in $3 \mathrm{ml}$ of $0.1 \mathrm{M}$ PBS. The optical density of the cell suspensions was adjusted to 0.3 at a wavelength of $600 \mathrm{~nm}\left(\approx 0.5 \times 10^{8}\right.$ CFU/ml) using a spectrophotometer (Spectronic 20; Bausch and Lomb, Rochester, NY), and 10-fold serial dilutions were performed to generate cell suspensions with $\approx 1 \times 10^{6} \mathrm{CFU} / \mathrm{ml}$. Using plastic spray bottles, cell suspensions of each strain were sprayed until run-off onto 2-week-old seedlings of each cucurbit species. Each seedling was incubated in a transparent plastic bag $(\approx 100 \%$ $\mathrm{RH})$ for $24 \mathrm{~h}$ and then the seedlings were incubated in a greenhouse as described above. Ten days after inoculation, seedlings were evaluated for BFB severity according to a previously described 1-to-9 rating scale (14). This experiment was repeated three times and each experiment included four replicates (individual plants) for each strain-host combination. Each plant was evaluated by three independent evaluators. In some instances, plants were damaged due to sunscald during incubation inside the plastic bags (these plants were excluded from the data set).

DNA:DNA hybridization. Bacterial cells in suspensions of $A$. citrulli strains (ZUM4000, DSM17060, and AAC00-1) containing $\approx 10^{9} \mathrm{CFU} / \mathrm{ml}$ were disrupted using a French pressure cell (Thermo Scientific, Waltham, MA) and DNA in the crude lysate was purified by chromatography on hydroxyapatite, as described (6). DNA:DNA hybridization was carried out as described (8), with modifications (16), using a Bio UV/VIS-spectrophotometer (Varian, Palo Alto, CA) model Cary 100 equipped with a Peltierthermostatted six-by-six multicell changer and a temperature controller with in situ temperature probe (Varian).

PFGE. DNA fingerprinting of $A$. citrulli strains was conducted by PFGE separation of whole-cell DNA digested with SpeI, as previously described (39). The strains analyzed in this experiment included representatives of groups I (Tw76, AAC98-17, AACAU9, M1, M6, 5, and AAC 203-57) and II (AAC92-17, AAC00-1, W1, W2, W4, W6, Tw148, Tw16, AAC94-12, AAC94-21, AAC206-102, and 7a1). Attempts were also made to generate SpeI PFGE DNA fingerprints for strains ZUM4000 and ZUM4001. After electrophoresis, agarose gels were stained in an ethidium bromide solution of $0.5 \mu \mathrm{g} / \mathrm{ml}$ for $30 \mathrm{~min}$ and destained in deionized water for $15 \mathrm{~min}$, and digital images were captured in tagged image file format (TIFF) using a Foto/UV 26 Transilluminator (FotoDyne Inc., Hartland, WI). DNA profiles were analyzed using Dice's coefficient of analysis and the unweighted pairwise group method with arithmetic mean algorithm generated a dendrogram to visualize relationships among strains (9). Data analysis and dendrogram generation were conducted using the BioNumerics software package (V. 3.00; Applied Math, SintMartens-Latem, Belgium).

rep-PCR. Attempts to generate PFGE profiles with genomic DNA from strains ZUM4000 and ZUM4001 consistently failed; therefore, rep-PCR was used to compare ZUM strains with representative group I (AACAU-9, AAC98-17, AAC203-57, Tw76, 5, M1, and M6) and group II (AAC00-1, AAC94-21, AAC94-12, AAC92-17, AAC206-21, Tw16, Tw148, 7a1, W1, W2, W4, and W6) strains. rep-PCR was conducted using $\approx 2 \mathrm{ng}$ of total DNA from each strain as template, the BOX-element primer, BOXA1R (5'-CTA CGG CAA GGC GAC GCT GAC-3'), and PuReTaq Ready-To-Go PCR Beads (GE Healthcare. Cleveland, OH), as previously described (38). PCR amplicons were separated on a $1 \%$ agarose gel run at $70 \mathrm{~V}$ for $7 \mathrm{~h}$ at $5^{\circ} \mathrm{C}$ and stained with ethidium bromide. Gel images were captured as TIFF files and DNA fingerprint data were analyzed as described above for PFGE data.

GC-FAME. All strains were grown on trypticase soy broth agar (Difco) for $24 \mathrm{~h}$ at $37^{\circ} \mathrm{C}$. Harvesting of the cells, saponification, methylation, and extraction were done precisely as recommended for taxonomic evaluation by the Sherlock Microbial Identification System (http://www.midi-inc.com/pdf/ MIS_Technote_101.pdf). The samples were analyzed on Gas Chromatograph 6890N (Agilent Technologies, Santa Clara, CA). The raw data were presented as the percentage of a specific fatty acid among all fatty acids.

OmniLog GEN III phenotype microArray assays. The metabolic characteristics of $A$. citrulli strains were analyzed using GEN III Microplates (Biolog Inc., Bremen, Germany). This method analyzes the respiration kinetics of a microorganism based on 94 phenotypic tests, including 71 sole carbon sources and 23 chemical sensitivity assays, thus providing a phenotype fingerprint. The microplates were inoculated with cells grown on LB agar plates for $\approx 20 \mathrm{~h}$ to produce a cell suspension in IF-A inoculation fluid (Biolog Inc.) with a cell density of $95 \%$ transmission. Each strain was ssayed in three independent repetitions. Purple coloration through the reduction of the tetrazolium redox 
dye was indicative of increased respiration and metabolic activity. Briefly, the microtiter plates with substrates, dye, and bacterial cells were loaded into the reader (OmniLog), which provided the appropriate incubation conditions (at $28^{\circ} \mathrm{C}$ for $96 \mathrm{~h}$ ) and automatically read the color intensity during tetrazolium reduction every $15 \mathrm{~min}$. The optical density data were further analyzed with the opm package for $\mathrm{R}$ software $(35,36)$, using its functionality for displaying the curve kinetics and aggregating curve parameters such as the maximum value (A) and the area under the curve by spline fitting algorithms.

Statistical analysis and data visualization. Statistical analysis and data visualization were performed using the $\mathrm{R}$ environment (29). The $\mathrm{R}$ package multcomp was utilized for multiple comparison of groups $(13,15)$. The $\mathrm{R}$ package opm was used to analyze OmniLog MicroArray Phenotype data $(35,36)$. The $\mathrm{R}$ package ggplot2 was used for data visualization (41). The $\mathrm{R}$ Sweave function (23) was used to document all analyses into Supplemental Appendix 1.

Deposit of sequences in GenBank. The sequence data for the $\mathrm{T} 3 \mathrm{~S}$ effector genes and the housekeeping gene gltA that were generated in this study are available under GenBank accession numbers KF944669 to KF944906. Partial sequences of the additional six housekeeping genes of strain ZUM4000 used for MLSA were deposited under GenBank accession numbers KJ584633 to KJ584638.

\section{RESULTS}

Clustering of $A$. citrulli strains based on T3S effector sequences concurs with previously described grouping scheme. We hypothesized that the repertoire of T3S effector genes in $A$. citrulli correlates with the distribution of strains into groups I and II. To assess this hypothesis, we cloned and sequenced 11 putative effector genes from $21 \mathrm{~A}$. citrulli strains that were isolated from various cucurbit hosts in different countries (Table 1). The genes selected for sequencing were predicted to be T3S effector genes based on the genome annotation of the group II A. citrulli strain AAC00-1. These genes showed homology to known T3S effectors in other plant-pathogenic bacteria (Supplemental Table 3). For comparative analyses of effectors, we also included the sequenced strain AAC00-1; thus, our population included $22 \mathrm{~A}$. citrulli strains. Also included was a housekeeping gene, gltA, which was found to possess the greatest variability from a list of seven multilocus sequence-typing (MLST) genes of A. citrulli (10).

Comparative analyses of effector genes revealed that, within each group, the strains exhibited a high level of similarity, show- ing only a few single-nucleotide polymorphisms (SNPs) in certain strains. The group I strain AAC98-17 showed a single SNP in position 439 (of the coding sequence) of gene Aave_1548, while strain 5 showed a single SNP at position 406 of gene Aave_3237 relative to the other group I strains. Regarding group II strains, a single SNP was found for strain Tw148 at position 1284 of gene Aave_3237. This strain also showed a single SNP in position 172 of the housekeeping gene gltA relative to the other group II strains. The information summarizing the number of SNP-based haplotypes in each group is provided in Table 2.

In contrast to the above picture, clear differences were detected between group I and II strains in their effector gene sequences. First, gene Aave_2708 was present in all group II strains tested but it could not be amplified from all tested group I strains, despite attempts using various primer combinations from either the flanking regions or the internal regions of the gene. Importantly, the draft genome sequence of the group I strain M6 generated by our research group confirmed the absence of this gene (unpublished results). Second, base deletions leading to ORF shifts were detected in genes Aave_2166 and Aave_3062 of all group I strains relative to group II strains (Table 1). For the latter, a nucleotide at position 558 of the ORF was deleted in all group I strains relative to group II strains, causing a frame shift and the occurrence of an early stop codon $\approx 220$ bp before its location in the group II intact gene. In the case of Aave_2166, all tested group I strains possessed a 123-bp sequence deletion spanning 72 bp upstream of the predicted start codon and $51 \mathrm{bp}$ downstream of it. Additionally, for most other effectors, group I and II strains clustered separately, with a total of 75 SNPs distinguishing the two groups when combining the T3S effector gene sequences for all strains tested (Table 2).

Evaluation of the ENC and GC content of T3S effector genes. In the sequenced strain AAC00-1, the 11 putative effector genes are distributed across the genome, from gene Aave_0277 until Aave_4728 (out of 4,796 genes), without detectable pathogenicity islands containing a cluster of effectors genes. We determined the ENC values for the 11 effector genes, compared with a set of reference genes from MLST databases and housekeeping genes $(10,11)$. The ENC value represents how far the codon usage of a gene departs from equal usage of synonymous codons, independently of gene length and amino acid composition (43). These values range from 20 to 61, where a value of 20 means that for every amino acid there is only one codon usage (extremely high bias), while a value of 61 means that the use of alternative synonymous codons is equally likely. Genes that are part of the core genome are more likely to have greater codon bias (ENC

TABLE 2. Single-nucleotide polymorphisms (SNPs) and amino acid substitutions in each type III secreted effector gene and gltA for group I and group II Acidovorax citrulli strains ${ }^{\mathrm{a}}$

\begin{tabular}{|c|c|c|c|c|c|c|c|c|c|c|}
\hline \multirow[b]{2}{*}{ Aave gene ${ }^{b}$} & \multicolumn{3}{|c|}{ Length of open reading frame (nt) } & \multicolumn{4}{|c|}{ Number of SNP-based haplotypes, nt (aa) } & \multicolumn{3}{|c|}{ SNPs between different groups, nt (aa) } \\
\hline & $\mathrm{I}$ & II & ZUM & I & II & ZUM & $\Sigma$ & $\mathrm{I} / \mathrm{II}$ & I/ZUM & II/ZUM \\
\hline 0277 & 1,554 & 1,554 & 1,554 & 1 & 1 & 1 & 3 & $3(2)$ & $2(1)$ & $3(1)$ \\
\hline 1548 & 1,455 & 1,455 & 1,455 & $2(2)$ & 1 & 1 & $4(4)$ & $33(15)$ & $4(2)$ & $33(15)$ \\
\hline $2166^{\mathrm{c}}$ & 1,026 & 1,077 & nd & 1 & 1 & nd & 2 & $3(3)$ & nd & nd \\
\hline 2173 & 1,119 & 1,119 & 1,119 & 1 & 1 & 1 & 3 & $1(1)$ & $1(1)$ & $2(2)$ \\
\hline 2708 & nd & 1,119 & nd & nd & 1 & nd & 1 & nd & nd & nd \\
\hline 2876 & 591 & 591 & 591 & 1 & 1 & 1 & 3 & 7 (3) & $5(2)$ & $2(1)$ \\
\hline $3062^{\mathrm{d}}$ & 1,241 & 1,242 & 1,242 & 1 & 1 & 1 & 3 & $16(7)$ & 71 (37) & $81(38)$ \\
\hline 3237 & 1,410 & 1,410 & nd & \multicolumn{2}{|c|}{$3(2)$} & nd & $3(2)$ & 0 & nd & nd \\
\hline 3452 & 1,122 & 1,122 & 1,122 & 1 & 1 & 1 & 3 & $7(2)$ & $6(2)$ & $7(4)$ \\
\hline 3462 & 1,527 & 1,527 & 1,527 & 1 & 1 & 1 & 3 & $5(2)$ & $5(2)$ & $6(2)$ \\
\hline $4728^{e}$ & 1,923 & 1,923 & 1,914 & \multicolumn{2}{|c|}{1} & 1 & 2 & 0 & $58(35)$ & $58(35)$ \\
\hline gltA & 486 & 486 & 486 & 1 & $2(2)$ & 1 & $4(2)$ & $3(0)$ & $4(0)$ & $1(0)$ \\
\hline
\end{tabular}

a Polymorphism at the DNA ( $\mathrm{nt}=$ nucleotide $)$ and protein $(\mathrm{aa}=$ amino acid $)$ levels of each effector and the housekeeping gene $\mathrm{glt} A$; $\mathrm{nd}=\mathrm{not}$ detected.

${ }^{\mathrm{b}}$ Aave gene number; according to AAC00-1 annotation.

${ }^{\mathrm{c}}$ Aave_2166 has a deletion of $123 \mathrm{bp}$ spanning $72 \mathrm{bp}$ upstream of the predicted start codon and an additional 51 bp downstream of it in all tested group I strains

d Aave_3062 has a 1-bp deletion at position 558 of the open reading frame in all tested group I strains.

e Aave_4728 has several indels in ZUM strains as compared with both group I and II strains. 
values closer to 20) than genes that were acquired by LGT. The reference genes used in this study included eight representative genes from each of the 11 clusters of orthologous genes (COGs) (http://www.mlst.net/misc/further.asp, http://pubmlst.org/data/), giving a total of 88 genes.

We observed little to no difference among the various $A$. citrulli strains based on their ENC values for the various T3S effector genes. Therefore, ENC values for effector and reference genes were compared only for sequence data from AAC00-1. This comparison revealed significantly higher ENC values for effector over reference genes (Fig. 1), meaning that, in A. citrulli, there is less bias in codon usage for genes encoding T3S effectors than other genes. In addition, there was a tendency toward a larger range of GC content of effector as compared with reference genes (Supplemental Figure 2). Altogether, these findings, as well as the high similarity of the putative effector genes with effector genes from other plant-pathogenic bacteria, strongly suggest that the assessed effector genes of $A$. citrulli were acquired through LGT.

Comparative analyses of T3S effector genes suggest the existence of a third group of $\boldsymbol{A}$. citrulli strains. Strains ZUM4000 and ZUM4001 were isolated from symptomatic watermelon seedlings in India in 2008. These strains were less virulent on watermelon than other $A$. citrulli strains and, in contrast to other strains, yielded negative reactions in certain serological tests and PCR reactions with some A. citrulli primers (B. Woudt, Syngenta Vegetable Seeds, personal communication). Similar to group I strains, the ZUM strains were found to lack gene Aave_2708. In contrast, the ZUM strains possessed a functional Aave_3062 gene, without the single base deletion observed for group I strains. On the other hand, although only 16 SNPs were found in gene Aave_3062 between group I and II strains, 71 SNPs were detected when comparing group I and ZUM strains, and 81 SNPs were detected between group II and ZUM strains (Table 2). Overall, 158 and 192 SNPs were detected when comparing the entire sequences of all assessed T3S effector ORFs of ZUM strains relative to group I and group II strains, respectively (Table 2).

Furthermore, two genes, Aave_2166 and Aave_3237, that were present in all tested group I and II strains, were not detected in the ZUM strains (Tables 1 and 2). Finally, although gene Aave_4728 was highly conserved among group I and II strains (no SNPs were detected among strains of the two groups), 58 SNPs and 21 indels in two different regions (one 15-base deletion and one 6-base insertion) were observed in the ZUM strains (Table 2).

In terms of sequence comparison, phylogenetic trees generated by the maximum parsimony method revealed that the majority of T3S effector genes from the ZUM strains clustered separately but closer to group I than group II strains (Fig. 2A, gene Aave_3452; Supplemental Figure 3, most other effectors). Only in the case of one effector gene, Aave_2876, did the ZUM strains cluster more closely to group II than group I strains (Fig. 2B). Another scenario was that the ZUM strains clustered as a third, completely distinguishable group (Fig. 2C, Aave_3062; Aave_2173 and Aave_4728). Overall, by comparative analyses of the combined sequences of all $(n=11)$ assessed T3S effector genes, the ZUM strains clustered separately from groups I and II (Fig. 2D). This observation is independent of inclusion of the outgroup taxon in the trees (Supplemental Figure 4A and B). In addition, a similar observation was obtained when the trees were generated using maximum likelihood and neighbor-joining methods.

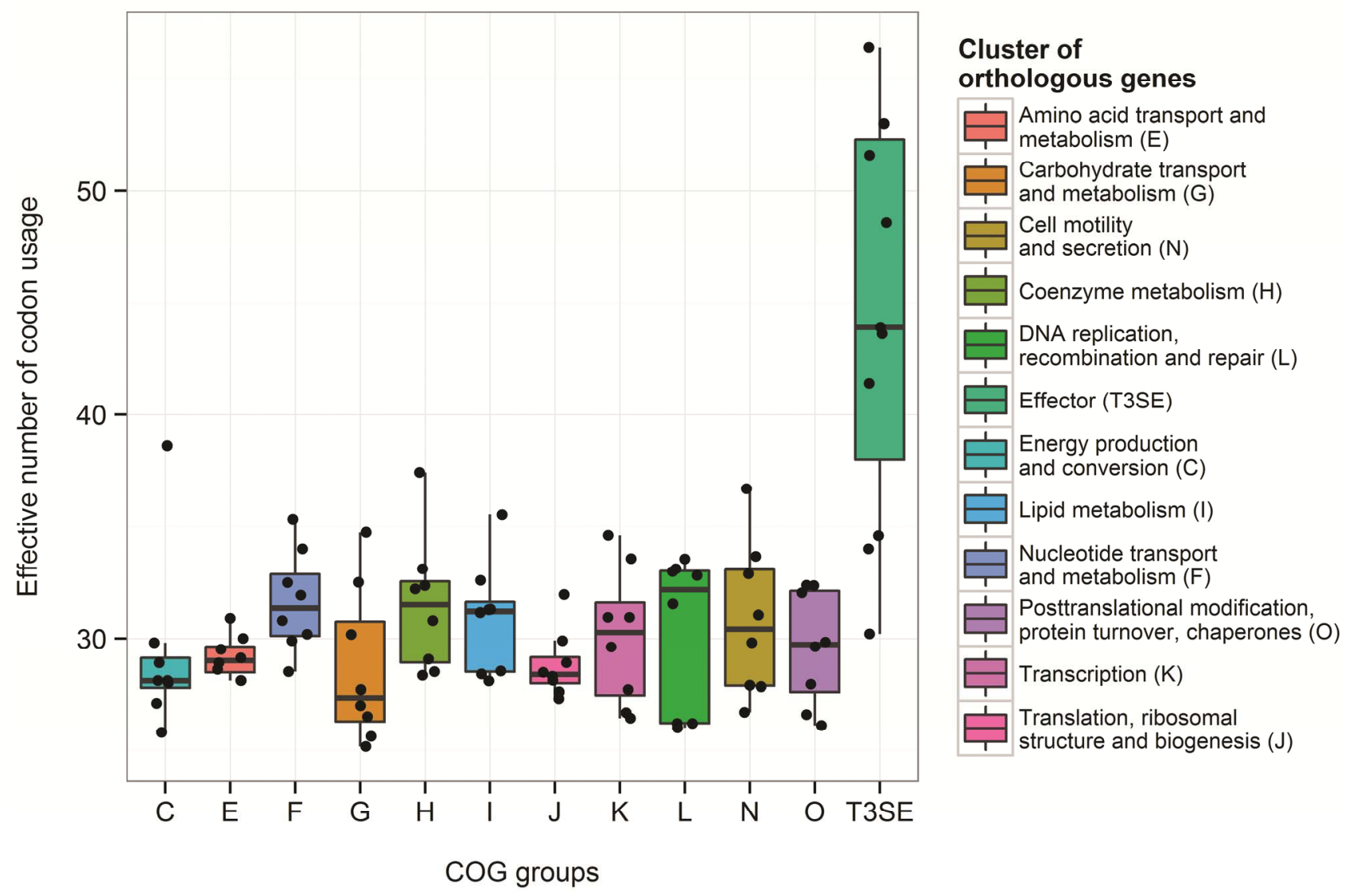

Fig. 1. Effective number of codons (ENC) usage of type III secreted effector genes relative to housekeeping genes in Acidovorax citrulli AAC00-1. ENC values of effectors genes were determined using DnaSP software. The obtained values were compared with ENC values of 88 housekeeping genes from 11 different clusters of orthologous genes ( 8 genes per category). ENC values range from 20 to 61, with 20 corresponding to high codon bias (for every amino acid, only one codon take place) and 61 corresponding to no codon bias (the use of synonymous codons is equally likely). Overall, the ENC values of effector genes were found to be significantly higher than those of housekeeping genes. The boxplots underlying the dots indicate minimum, first quartile, median, third quartile, and maximum values. 
We recently sequenced the genome of one of the ZUM strains, ZUM4000 (draft sequence; unpublished data). We performed a MLSA of seven conserved genes, using the sequences from ZUM4000 and selected group I and II strains, available from the report of Feng et al. (10). Despite the lower level of variability of conserved genes relative to effector genes, these phylogenetic analyses also led to a clustering into three different groups, with the ZUM strain clustering separately from group I and II strains (Supplemental Figure 5). These results strengthened the hypothesis that there are at least three different groups of A. citrulli strains, and variability among T3S effector genes reflects divergence of this species into three distinct lineages.

ZUM strains are less virulent than group I and II strains. The virulence of selected $A$. citrulli strains (representing different PFGE-based haplotypes from previous characterizations) (Table 1) was compared on melon, watermelon, and squash seedlings. A high variability in virulence was observed among strains belonging to the same group, and also between replicates of the same strain. Nevertheless, in terms of comparison of group I and II strains, results from virulence assays were in accordance with previous reports $(3,38,39)$. Group I and II strains did not differ significantly in their virulence on watermelon, while group I strains induced the highest degrees of disease severity on melon and squash (Fig. 3; statistical analyses). Exceptions were the strains isolated in Taiwan, Tw76 (group I), Tw16, and Tw148 (group II), which, in contrast to typical group I and II strains characterized in this and other studies, showed very low levels of virulence on the three tested hosts (Fig. 3). This could be due to loss of virulence of these strains during storage. The fact that the three strains were obtained from the same collection supports this assumption. Also, as previously reported (38), squash plants were less susceptible than melon and watermelon. In agreement with preliminary information (B. Woudt, personal communication), the ZUM strains were significantly less virulent than group I and II strains on watermelon but also on melon and squash (Fig. 3).

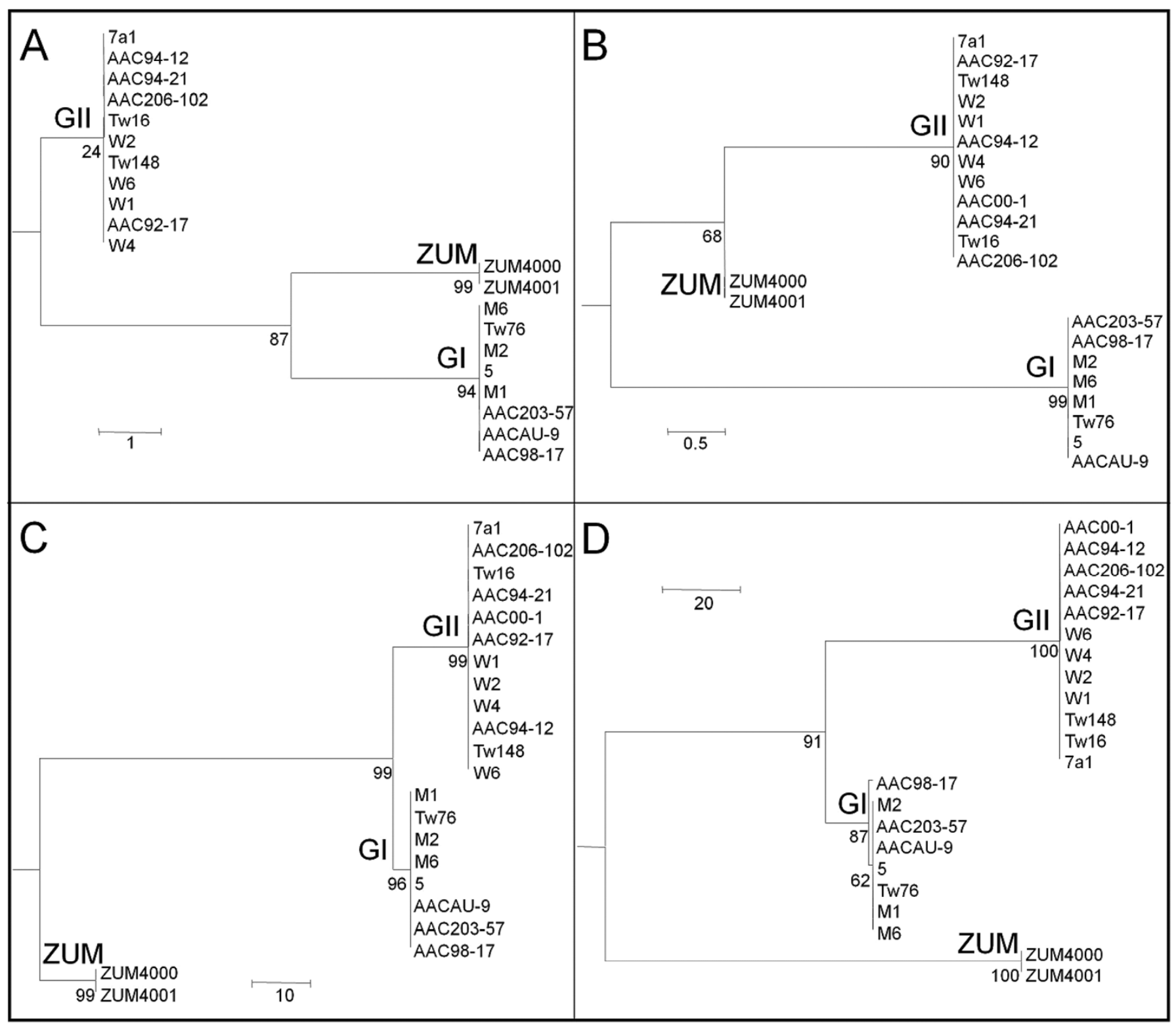

Fig. 2. Phylogenetic trees of representative type III secreted effector gene sequences of Acidovorax citrulli. Phylogenetic trees based on the nucleotide sequences of some effector genes using the maximum parsimony method with 1,000 replicates bootstrap test. GI = group I and GII = group II. A, Tree based on Aave_3452 sequence data; the ZUM strains cluster closer to group I strains. B, Tree based on Aave_2876 sequence data; the ZUM strains cluster closer to group II strains. C, Tree based on Aave_3062 sequence data; the ZUM strains cluster as a third distinguished group. D, Tree based on sequences of all (11) effector genes combined; the ZUM strains cluster as a third group. 
DNA:DNA hybridization confirms that the ZUM strains belong to species $A$. citrulli. Based on phylogenetic analyses of effector and conserved genes and other features, the ZUM strains appear to represent a distinct group, relative to the previously characterized groups I and II of A. citrulli. Recently, Makizumi et al. (25) isolated Acidovorax strains from infected cucurbits that were different from $A$. citrulli based on $16 \mathrm{~S}$ ribosomal DNA sequences, indicating that other Acidovorax spp. may infect cucurbit plants and induce weak to mild symptoms. Taking this study into consideration, we sought to determine the identity of a representative ZUM strain using DNA:DNA hybridization, which is the "gold standard" for defining bacterial species (33). ZUM4000 was hybridized with both the sequenced strain AAC00-1 and the type strain DSM17060. The percentages of hybridization between DNA of ZUM4000 and DSM17060 or AAC00-1 were 87.5 and $78.6 \%$, respectively. As a control comparison, the percentage of hybridization between AAC00-1 and DSM17060 was $84.8 \%$. Because a threshold value of $>70 \%$ DNA-DNA similarity meets the criteria for strains belonging to the same species (40), these results confirmed that strain ZUM4000 belongs to species A. citrulli. This is also likely for ZUM4001 that was shown to be identical to ZUM4000 based on T3S effector sequences. In fact, because ZUM4000 and ZUM4001 were identical or highly similar in several other features (see below), and were isolated from the same batch of infected seedlings, it is likely that these strains are clonal.

Characterization of ZUM strains by DNA fingerprinting, carbon utilization, and GC-FAME. Thus far, T3S effector sequences and virulence data indicated that group I and II of A. citrulli strains are distinguishable based on their effectors' repertoire and that the ZUM strains represent a third, previously uncharacterized group. An additional objective of this study was to determine whether the ZUM strains can be considered as a third group in terms of characteristics that are not directly associated with pathogenicity. To accomplish this objective, strains used in this study were evaluated by DNA fingerprinting (PFGE and rep-PCR), carbon substrate utilization assays (OmniLog PM), and composition of fatty acids by GC-FAME.

As expected from previous reports $(3,38,39)$, PFGE of SpeIdigested DNA fragments clearly distinguished the representative group I and II strains (Supplemental Figure 6). However, in several attempts, we failed to generate PFGE profiles for the ZUM strains, probably due to DNA degradation during sample preparation $(19,37)$. This was also the case when several other

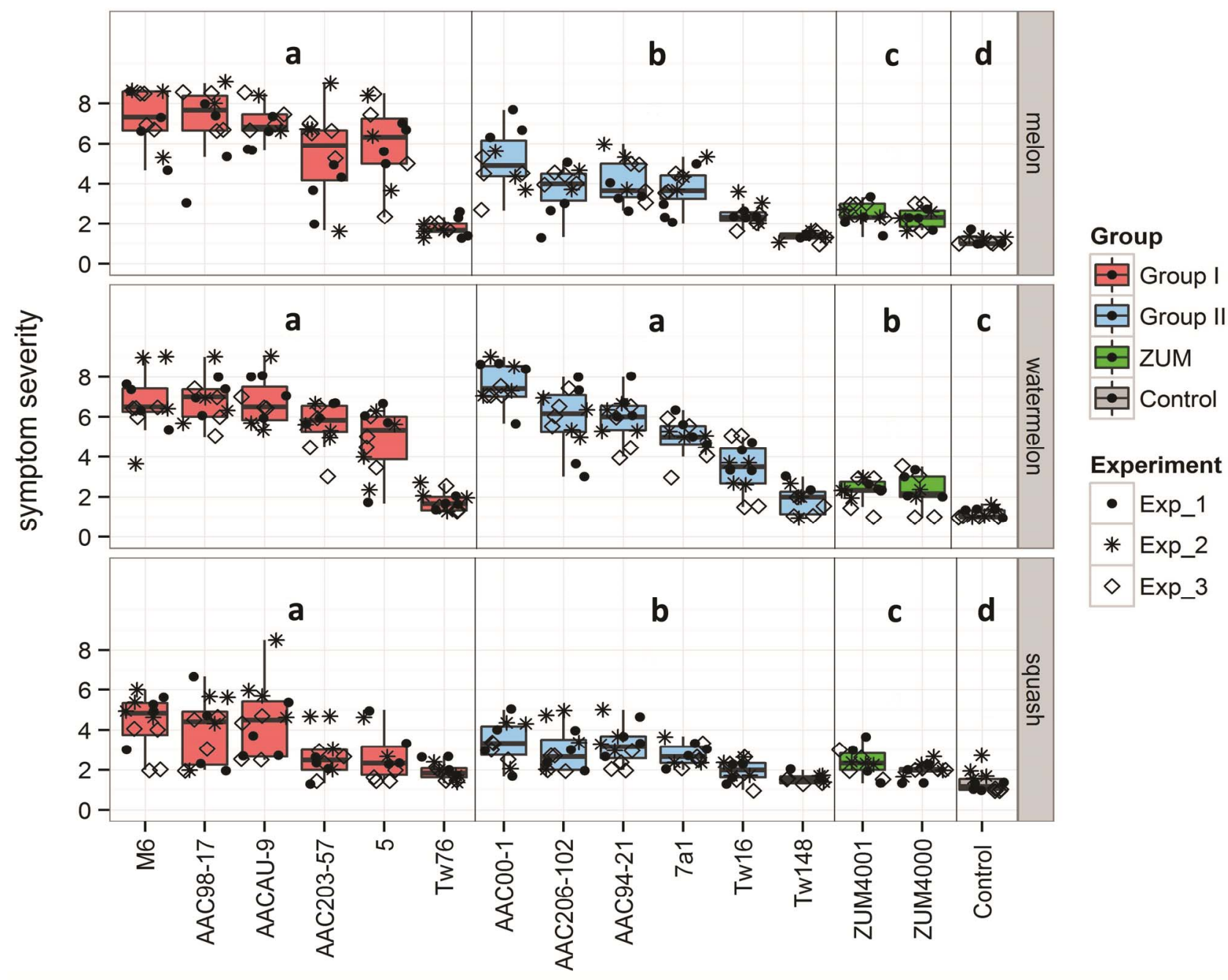

strain

Fig. 3. Disease severity induced by selected Acidovorax citrulli strains on different cucurbit seedlings. Fourteen-day-old seedlings of three different hosts (melon, watermelon, and squash) were spray inoculated with suspensions of 14 representative A. citrulli strains at $\approx 10^{6} \mathrm{CFU} / \mathrm{ml}$ or phosphate-buffered saline buffer (as a negative control). Seedlings were evaluated after 10 days after inoculation using a previously described 1-to-9 scale (14). Each treatment (plant-strain combination) was composed of up to four replicates (every dot represents a different repetition) and the experiment was repeated three times (Exp_1, Exp_2, and Exp_3). Different letters indicate significant differences $(P=0.05)$ among different groups (group I, group II, ZUM strains, and control) in each host plant. 
restriction enzymes were used (data not shown). Therefore, strains were assessed by rep-PCR using the BOX primer, which was also shown to effectively differentiate group I and II strains $(3,38)$. BOX-PCR analysis not only differentiated group I and II strains but also clustered the ZUM strains as a third group (Fig. 4).

In contrast, GC-FAME and carbon utilization assays did not clearly differentiate the ZUM strains as a third group. However, these assays were also less able to discriminate between group I and II strains compared with T3S effector gene analyses and DNA fingerprinting. For example, based on GC-FAME analysis, the group I strain M1 clustered with some group II strains, while the group II strain AAC00-1 was closer to some group I strains (Fig. 5). Despite this, detailed observations of several individual fatty acids such as 18:1 w7c and 14:0 revealed clear differences between the ZUM strains and the others (Supplemental Figure 7). Regarding carbon utilization data, the group II strain AAC92-17 clustered far away from the rest of the group II strains, and the same pattern was observed for the group I strain Tw76 relative to the rest of group I strains (Fig. 6).

\section{DISCUSSION}

Like other gram-negative plant-pathogenic bacteria, A. citrulli requires a functional T3SS to cause disease $(1,17)$. Annotation of the A. citrulli group II strain AAC00-1 revealed several genes encoding putative T3S effectors, based on their similarities to validated effectors from other plant-pathogenic bacteria. Based on gene organization, sequence analysis, and regulation, hrp clusters are divided into two classes: class I contains Pseudomonas syringae and enteric plant-pathogenic bacteria, while class II contains Xanthomonas spp. and Ralstonia solanacearum $(2,5)$. Based on sequence analysis and cluster organization, the A. citrulli hrp

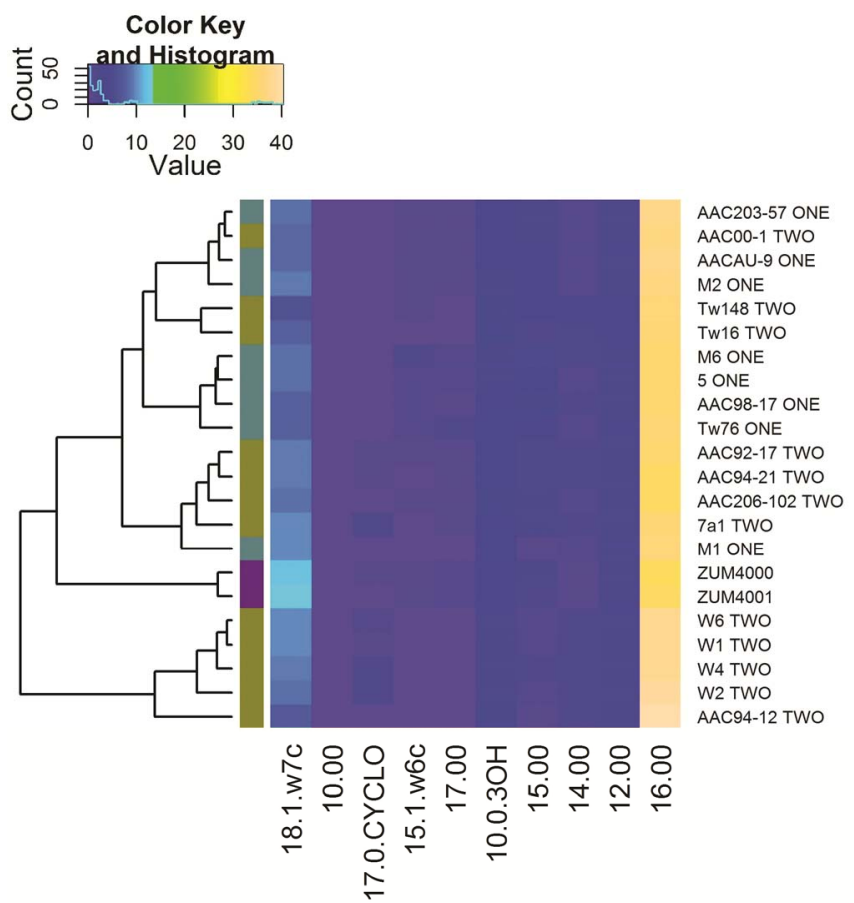

Fig. 5. Heat map based on gas chromatography fatty acid methyl ester analysis. Heat map represents color-coded abundance of short chain fatty acids in different Acidovorax citrulli strains. The rectangle at the left indicates the group of each strain: pale blue = group I, brown-yellow = group II, and purple $=$ ZUM strains $($ group III). Values of each strain sum up to 100 . However, fatty acids that could not be unequivocally identified are not shown. The two ZUM strains are more closely related to group II strains. The main difference between the ZUM strains and the others are in fatty acid 18:1 w7c.

\section{Similarity \%}

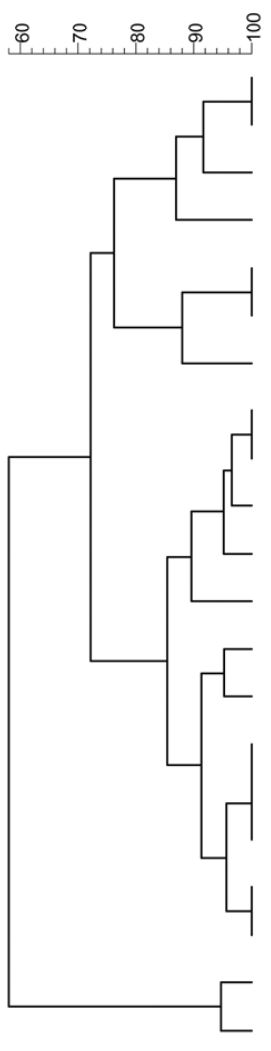

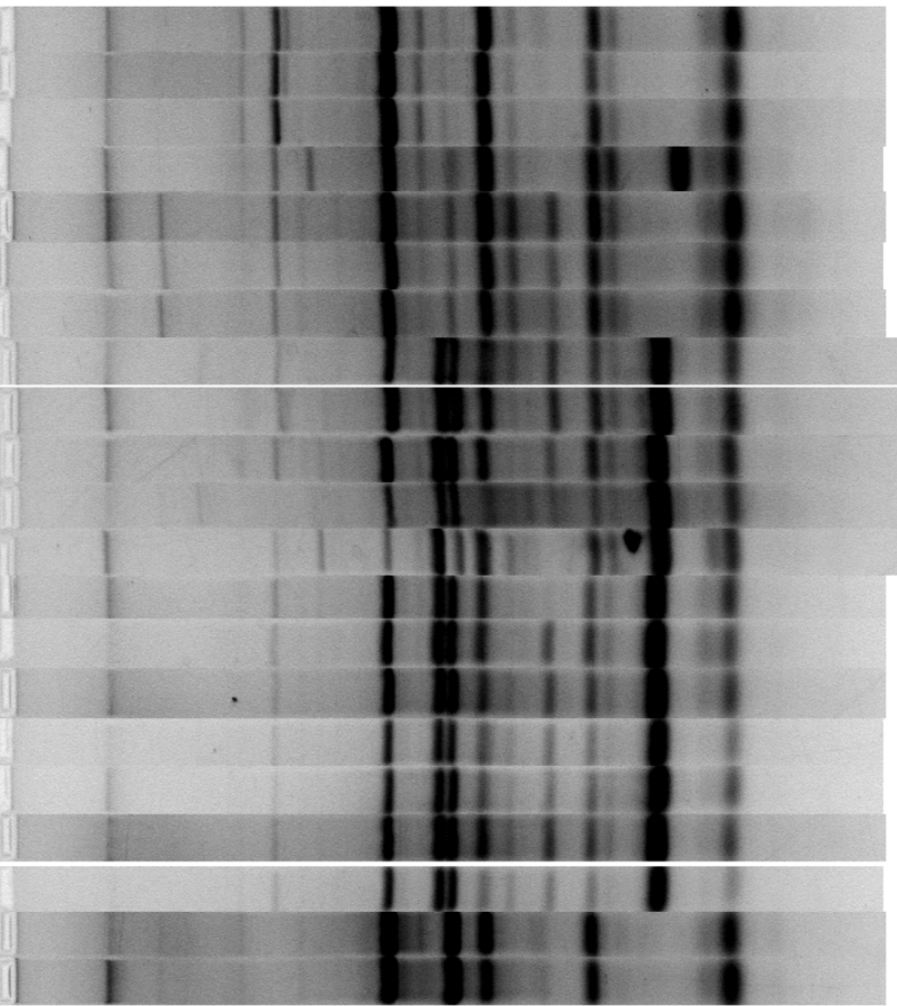

Strain

PFGE haplotype

$\begin{array}{ll}5 & \text { B21 } \\ \text { M1 } & \text { B21 } \\ \text { Tw76 } & \text { B13 (Y) } \\ 98-17 & \text { B6 (N) } \\ \text { M6 } & \text { B21 } \\ \text { AU-9 } & \text { B5 (M) } \\ \text { 203-57 } & \text { B9 (R) } \\ \text { W4 } & \text { A13 } \\ \text { W2 } & \text { A13 } \\ \text { W6 } & \text { A20 } \\ 206-102 & \text { A13 } \\ \text { 92-17 } & \text { A4 (D) } \\ \text { 94-12 } & \text { A11 (W) } \\ \text { 94-21 } & \text { A3 (C) } \\ \text { 00-1 } & \text { A1 (A) } \\ \text { Tw16 } & \text { A6 (G) } \\ \text { 7a1 } & \text { A23 } \\ \text { W1 } & \text { A1(A) } \\ \text { Tw148 } & \text { A6 (G) } \\ \text { ZUM 4001 } & \text { NA } \\ \text { ZUM4000 } & \text { NA }\end{array}$

Fig. 4. Repetitive polymerase chain reaction (rep-PCR) profiles of selected Acidovorax citrulli strains. rep-PCR profiles were performed using the BOXA1R primer (BOX-PCR). Profiles were analyzed using Dice's coefficient of analysis and the unweighted pairwise group method with arithmetic mean algorithm generated a dendrogram to visualize relationships among strains. 
cluster belongs to class II (4). Therefore, it is not surprising that most putative T3S effector genes detected in the AAC00-1 genome are closely related to effector genes from Xanthomonas spp. and $R$. solanacearum.

The fact that the 11 effector genes investigated in this study were detected based on their similarity to effectors of other plantpathogenic bacteria strongly suggests that these effector genes were assimilated by LGT. LGT is generally reflected by differences in GC content and codon usage bias relative to the core genome $(7,22)$. Indeed, a comparison between the 11 effector genes and 88 housekeeping genes from strain AAC00-1 repre- senting various COG classes and spread throughout the genome revealed that the ENC was significantly higher in the effector genes (Fig. 1), which also showed a more scattered profile of GC content. These data support the notion that the effector genes assessed in this study were acquired by $A$. citrulli by LGT.

To date, there have been no reports on experimental and functional characterization of $A$. citrulli $\mathrm{T} 3 \mathrm{~S}$ effectors. In the present study, we cloned and sequenced the ORFs of 11 putative T3S effectors from a collection of A. citrulli strains. Our hypothesis was that, due to the crucial role of $\mathrm{T} 3 \mathrm{~S}$ effectors in pathogenicity, the effector repertoire of $A$. citrulli strains may
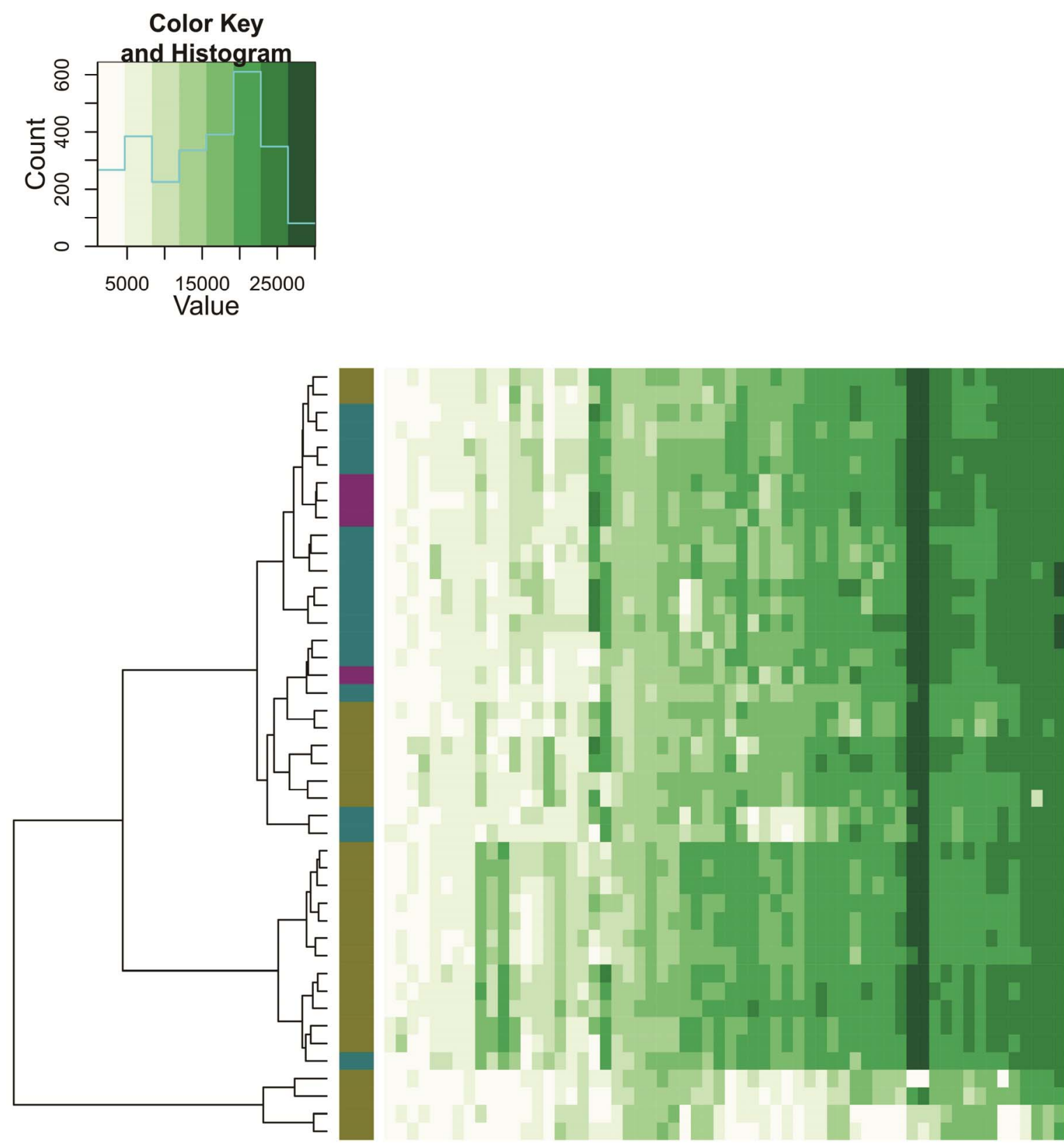

AAC92-17 2nd Group II AAC92-17 1st Group II AACAU-9 1st Group I M6 1st Group I M6 2nd Group । M6 2nd Group 1 ZUM4000 1st ZUM4001 1st ZUM4001 2nd M1 2nd Group I 5 2nd Group I 2nd Group AAC98-17 1st Group | AAC98-17 2nd Group I AAC203-57 1st Group I AACAU-9 2nd Group I M2 2nd Group I ZUM4000 2nd M1 1st Group I Tw16 1st Group II Tw16 2nd Group II AAC94-21 1st Group II AAC94-21 2nd Group II AAC94-12 2nd Group II AAC94-12 1st Group II Tw76 2nd Group I Tw76 1st Group I W4 2nd Group II W1 2nd Group II W6 1st Group I W11 1st Group Wh tst Group II W6 2nd Group I W2 2nd Group II W4 1st Group II 7a1 1st Group II 7a1 2nd Group II W2 1st Group AAC206-102 2nd Group II AAC206-102 1st Group II AAC203-57 2nd Group I Tw148 1st Group II Tw148 2nd Group AAC00-1 2nd Group II AAC00-1 1st Group II

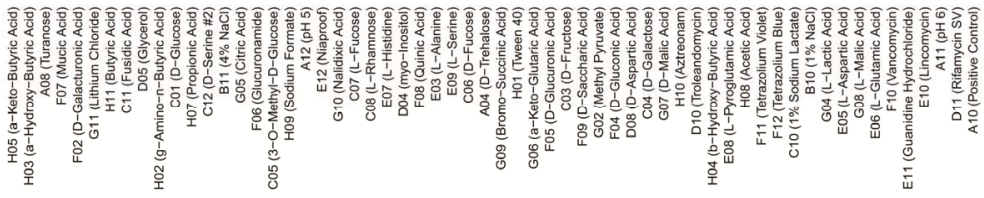

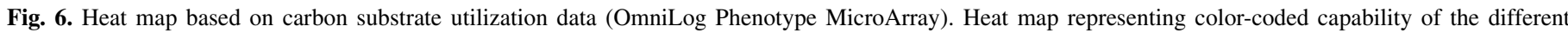

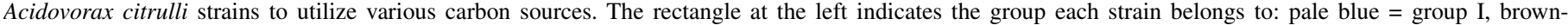

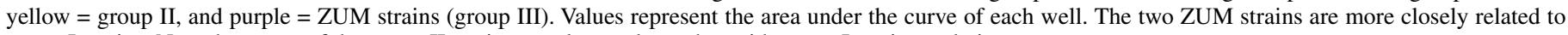
group I strains. Note that some of the group II strains are clustered together with group I strains and vice-versa. 
correlate with the preferential host association observed for group I and II strains $(3,38,39)$. In support of this hypothesis, we found that group I and II strains of A. citrulli cluster separately based on effector sequences (Table 1; Fig. 2). First, one effector present in all assessed group II strains, Aave_2708 (according to the AAC00-1 annotation), was absent in all group I strains. Second, two effectors, Aave_2166 and Aave_3062, had base deletions in all group I strains, likely affecting their functionality. Third, although a high degree of conservation was found among effector sequences within each group, several SNPs (often leading to amino acid substitutions) were detected for most effector genes when comparing strains among groups (Table 2). In contrast, few SNPs with no amino acid substitutions were observed for the housekeeping gene gltA between the groups (Table 2) which, according to a recent MLST study, was shown to be the most variable housekeeping gene among the ones tested (10). This suggests a rather strong degree of divergence in the effector genes between groups I and II compared with housekeeping genes. In agreement with previous reports $(3,38,39)$, virulence assays on various cucurbit hosts (Fig. 3), DNA-fingerprinting by BOX-PCR (Fig. 4), and PFGE all distinguished between strains of both groups.

In the present study, we included two strains, ZUM4000 and ZUM4001 (ZUM strains), which were isolated from symptomatic watermelon seedlings in India. We included these strains because previous unpublished information suggested that they behaved differently than typical A. citrulli strains. Briefly, the ZUM strains appeared to be less virulent than other strains on watermelon, reacted negatively with Agdia and Envirologix immunostrips diagnostic for $A$. citrulli, and did not yield PCR products for certain A. citrulli primers (B. Woudt, personal communication). Overall, this information suggested that these strains could constitute a new group of $A$. citrulli strains. Indeed, comparative analyses of effector genes as well as housekeeping genes supported that the ZUM strains represent a third, previously unreported $A$. citrulli group. In contrast with group I and II strains, genes Aave_2166 and Aave_3237 could not be amplified in these strains. In addition, a much higher number of SNPs were detected when comparing effector genes from ZUM strains with those of group I and II than when comparing between group I and II strains (Table 2). The maximum parsimony method was preferred for constructing phylogenetic trees because the amount of variation in each sequence was relatively small (26); however, results with this method were confirmed by maximum likelihood and neighbor-joining methods. A phylogenetic tree based on all effector sequences confirmed that the ZUM strains form a third, unique clade (Fig. 2D). The picture emerging from phylogenetic analysis of effector genes was confirmed by MLSA of seven housekeeping genes and by BOX-PCR profiling (Fig. 4), in which the ZUM strains clustered separately from group I and II. DNA:DNA hybridization assays performed with ZUM4000, confirmed that this strain belongs to the A. citrulli species. The same is likely true for ZUM4001 because previous evidence and results from this study indicate that these strains are clonal.

In agreement with previous preliminary observations, the ZUM strains were consistently less virulent than group I and II strains on watermelon but also on melon and squash seedlings (Fig. 3). We hypothesize that the lack of some effector genes in these strains, as well as the high number of base substitutions in other effectors relative to group I and II strains, contribute, at least partially, to the observed reduced virulence of these strains. However, this hypothesis should be further verified by experimental characterization of different T3S effector genes. The reduced virulence of these strains and, consequently, their likely reduced epidemiological potential could also explain why strains belonging to the new group have not been commonly isolated from BFB outbreaks. In contrast to comparative analyses of effector genes, virulence assays, and BOX-PCR, GC-FAME and carbon substrate utilization assays failed to clearly discriminate the ZUM strains from group I and II strains. However, these methods were also less sensitive than the other analyses for discriminating between group I and II strains (Figs. 5 and 6).

Yan et al. (44) recently characterized the genetic diversity of A. citrulli in China using MLST and PFGE. The authors reported that, based on the MLST analysis, one of the strains (Fc380, isolated in the United States) did not cluster with group I or II strains. However, this separated singleton was visible only when performing eBURST analysis, whereas phylogenetic analyses and PFGE clearly positioned this strain within group II. In addition, further verification of the sequence data of strain $\mathrm{Fc} 380$ revealed a high number of base insertions and deletions causing frame shifts in some of the assessed housekeeping genes (three of five genes that showed variability among the different strains). Because the number of indels leading to frame shifts is unlikely for housekeeping genes, this suggests the occurrence of sequencing errors for this strain. Therefore, it is unlikely that the singleton reported by Yan et al. (44) represents a new distinguished group of $A$. citrulli.

In conclusion, this study showed that group I and II strains of A. citrulli can be clearly distinguished based on their effector repertoire. It is possible that the difference in the arsenal of effectors contributes to host preference association of the groups. In this regard, host selection pressure (e.g., watermelon versus non-watermelon cucurbits) could have contributed to shaping differences in T3S effectors, because different hosts may carry different sets of pathogenicity targets or resistance proteins that evolved independently. We also report, for the first time, the occurrence of a third, clearly distinguished group of A. citrulli. It is important to stress that the current number of predicted T3S effectors in A. citrulli, which was based on similarity searches, is likely underestimated. Moreover, this study was based on predicted effectors from the annotated group II strain AAC00-1. As we found that some AAC00-1 or group II effectors are not present or are not functional in group I and ZUM strains, it is also possible that group I or ZUM strains carry functional, groupspecific effectors. We are currently searching for new, putative T3S effectors in a range of $A$. citrulli genomes. In addition, we are generating mutant strains impaired in selected effectors or carrying swapped effectors from other groups to assess the contribution of individual effectors to virulence and host preferential association. Effectors showing significant contribution to virulence or host preference could be used in the future screens for sources of BFB disease resistance, which are lacking to date.

\section{ACKNOWLEDGMENTS}

This work was supported by research grant US-4216-09 from the United States-Israel Binational Agriculture Research and Development (BARD) Fund. A short-term research visit of N. Eckshtain-Levi to the Leibniz Institute DSMZ was supported by a Minerva Short-Term Research Grant and a fellowship from the Otto Warburg Center for Agricultural Biotechnology. J. Sikorski was supported by grant DFG SI1352/1-2. We thank I. Assouline, B Woudt, and H.-C. Huang for kindly providing A. citrulli strains for this study; and A. Castro-Sparks and B. Sträubler for technical assistance.

\section{LITERATURE CITED}

1. Bahar, O., and Burdman, S. 2010. Bacterial fruit blotch: A threat to the cucurbit industry. Israel J. Plant Sci. 58:19-31.

2. Bogdanove, A. J., Beer, S. V., Bonas, U., Boucher, C. A., Collmer, A., Coplin, D. L., Cornelis, G. R., Huang, H. C., Hutcheson, S. W., Panopoulos, N. J., and Van Gijsegem, F. 1996. Unified nomenclature for broadly conserved $h r p$ genes of phytopathogenic bacteria. Mol. Microbiol. 20:681-683.

3. Burdman, S., Kots, N., Kritzman, G., and Kopelowitz, J. 2005. Molecular, physiological, and host-range characterization of Acidovorax avenae subsp. citrulli isolates from watermelon and melon in Israel. Plant Dis. 89:1339-1347 
4. Burdman, S., and Walcott, R. 2012. Acidovorax citrulli: Generating basic and applied knowledge to tackle a global threat to the cucurbit industry. Mol. Plant Pathol. 13:805-815.

5. Buttner, D., and Bonas, U. 2002. Getting across-bacterial type III effector proteins on their way to the plant cell. EMBO J. 21:5313-5322.

6. Cashion, P., Holder-Franklin, M. A., McCully, J., and Franklin, M. 1977. A rapid method for the base ratio determination of bacterial DNA. Anal. Biochem. 81:461-466.

7. Daubin, V., Lerat, E., and Perriere, G. 2003. The source of laterally transferred genes in bacterial genomes. Genome Biol. 4:R57.

8. De Ley, J., Cattoir, H., and Reynaerts, A. 1970. The quantitative measurement of DNA hybridization from renaturation rates. Eur. J. Biochem. 12:133-142.

9. Dice, L. R. 1945. Measures of the amount of ecologic association between species. Ecology 26:297-302.

10. Feng, J., Schuenzel, E. L., Li, J. Q., and Schaad, N. W. 2009. Multilocus sequence typing reveals two evolutionary lineages of Acidovorax avenae subsp. citrulli. Phytopathology 99:913-920.

11. Gil, R., Silva, F. J., Pereto, J., and Moya, A. 2004. Determination of the core of a minimal bacterial gene set. Microbiol. Mol. Biol. Rev. 68:518537.

12. Hanahan, D. 1983. Studies on transformation of Escherichia coli with plasmids. J. Mol. Biol. 166:557-580.

13. Herberich, E., Sikorski, J., and Hothorn, T. 2010. A robust procedure for comparing multiple means under heteroscedasticity in unbalanced designs. PLoS One 5:e9788.

14. Hopkins, D. L., and Thompson, C. M. 2002. Evaluation of Citrullus sp. germplasm for resistance to Acidovorax avenae subsp. citrulli. Plant Dis. 86:61-64.

15. Hothorn, T., Bretz, F., and Westfall, P. 2008. Simultaneous inference in general parametric models. Biometric. J. 50:346-363.

16. Huss, V. A., Festl, H., and Schleifer, K. H. 1983. Studies on the spectrophotometric determination of DNA hybridization from renaturation rates. Syst. Appl. Microbiol. 4:184-192.

17. Johnson, K. L., Minsavage, G. V., Le, T., Jones, J. B., and Walcott, R. R. 2011. Efficacy of a nonpathogenic Acidovorax citrulli strain as a biocontrol seed treatment for bacterial fruit blotch of cucurbits. Plant Dis. 95:697-704.

18. King, E. O., Ward, M. K., and Raney, D. E. 1954. Two simple media for the demonstration of pyocyanin and fluorescin. J. Lab. Clin. Med. 44:301-307.

19. Klaassen, C. H., van Haren, H. A., and Horrevorts, A. M. 2002. Molecular fingerprinting of Clostridium difficile isolates: Pulsed-field gel electrophoresis versus amplified fragment length polymorphism. J. Clin. Microbiol. 40:101-104.

20. Latin, R. X., and Rane, K. K. 1990. Bacterial fruit blotch of watermelon in Indiana. Plant Dis. 74:331.

21. Latin, R. X., and Hopkins, D. L. 1995. Bacterial fruit blotch of watermelon. The hypothetical exam question becomes reality. Plant Dis. 79:761-765.

22. Lawrence, J. G., and Ochman, H. 1998. Molecular archaeology of the Escherichia coli genome. Proc. Natl. Acad. Sci. USA 95:9413-9417.

23. Leisch, F. 2002. Sweave: Dynamic generation of statistical reports using literate data analysis. Pages 575-580 in: Compstat. W. Härdle and B. Rönz, eds. Physica-Verlag, Heidelberg, Germany.

24. Librado, P., and Rozas, J. 2009. DnaSP v5: A software for comprehensive analysis of DNA polymorphism data. Bioinformatics 25:1451-1452.

25. Makizumi, Y., Igarashi, M., Gotoh, K., Murao, K., Yamamoto, M., Udonsri, N., Ochiai, H., Thummabenjapone, P., and Kaku, H. 2011. Genetic diversity and pathogenicity of cucurbit-associated Acidovorax. J. Gen. Plant Pathol. 77:24-32.

26. Mount, D. W. 2008. Choosing a method for phylogenetic prediction. Cold Spring Harb. Protoc. doi:10.1101/pdb.ip49
27. Mudgett, M. B. 2005. New insights to the function of phytopathogenic bacterial type III effectors in plants. Annu. Rev. Plant Biol. 56:509-531.

28. O'Brien, R. G., and Martin, H. L. 1999. Bacterial blotch of melons caused by strains of Acidovorax avenae subsp. citrulli. Aust. J. Exp. Agric. 39:479-485.

29. R Development Core Team. 2013. R: A Language and Environment for Statistical Computing. R Foundation for Statistical Computing, Vienna

30. Schaad, N. W., Postnikova, E., Sechler, A., Claflin, L. E., Vidaver, A. K. Jones, J. B., Agarkova, I., Ignatov, A., Dickstein, E., and Ramundo, B. A. 2008. Reclassification of subspecies of Acidovorax avenae as A. Avenae (Manns 1905) emend., A. cattleyae (Pavarino, 1911) comb. nov., A. citrulli Schaad et al., 1978) comb. nov., and proposal of A. oryzae sp. nov. Syst. Appl. Microbiol. 31:434-446.

31. Schneider, A., and Cannarozzi, G. M. 2009. Support patterns from different outgroups provide a strong phylogenetic signal. Mol. Biol. Evol. 26:1537-1719.

32. Somodi, G. C., Jones, J. B., Hopkines, D. L., Stall, R. E., Kuchark, T. A., Hode, N. C., and Watterson, J. C. 1991. Occurrence of a bacterial watermelon fruit blotch in Florida. Plant Dis. 75:1053-1056.

33. Stackebrandt, E., and Goebel, B. M. 1994. Taxonomic note: A place for DNA-DNA reassociation and 16S rRNA sequence analysis in the present species definition in bacteriology. Int. J. Syst. Bacteriol. 44:846-849.

34. Tamura, K., Peterson, D., Peterson, N., Stecher, G., Nei, M., and Kumar, S. 2011. MEGA5: Molecular evolutionary genetics analysis using maximum likelihood, evolutionary distance, and maximum parsimony methods. Mol. Biol. Evol. 28:2731-2739.

35. Vaas, L. A., Sikorski, J., Hofner, B., Fiebig, A., Buddruhs, N., Klenk, H P., and Goker, M. 2013. opm: An R package for analysing OmniLog(R) phenotype microarray data. Bioinformatics 29:1823-1824.

36. Vaas, L. A., Sikorski, J., Michael, V., Goker, M., and Klenk, H. P. 2012. Visualization and curve-parameter estimation strategies for efficient exploration of phenotype microarray kinetics. PLoS One 7:e34846.

37. Valverde, A., Hubert, T., Stolov, A., Dagar, A., Kopelowitz, J., and Burdman, S. 2007. Assessment of genetic diversity of Xanthomonas campestris pv. campestris isolates from Israel by various DNA fingerprinting techniques. Plant Pathol. 56:17-25.

38. Walcott, R. R., Fessehaie, A., and Castro, A. C. 2004. Differences in pathogenicity between two genetically distinct groups of Acidovorax avenae subsp. citrulli on cucurbit hosts. J. Phytopathol. 152:277-285.

39. Walcott, R. R., Langston, D. B., Sanders, F. H., and Gitaitis, R. D. 2000. Investigating intraspecific variation of Acidovorax avenae subsp. citrulli using DNA fingerprinting and whole cell fatty acid analysis. Phytopathology 90:191-196.

40. Wayne, L. G., Brenner, D. J., Colwell, R. R., Grimont, P. A. D., Kandler, O., Krichevsky, M. I., Moore, L. H., Moore, W. E. C., Murray, R. G. E., and Stackebrandt, E. 1987. Report of the Ad Hoc committee on reconciliation of approaches to bacterial systematics. Int. J. Syst. Bacteriol. 37:463-464.

41. Wickham, H. 2009. ggplot2: Elegant Graphics for Data Analysis. Springer-Verlag, New York.

42. Willems, A., Goor, M., Thielemans, S., Gillis, M., Kersters, K., and De Ley, J. 1992. Transfer of several phytopathogenic Pseudomonas species to Acidovorax as Acidovorax avenae subsp. avenae subsp. nov., comb. nov., Acidovorax avenae subsp. citrulli, Acidovorax avenae subsp. cattleyae, and Acidovorax konjaci. Int. J. Syst. Bacteriol. 42:107-119.

43. Wright, F. 1990. The 'effective number of codons' used in a gene. Gene 87:23-29.

44. Yan, S., Yang, Y., Wang, T., Zhao, T., and Schaad, N. W. 2013. Genetic diversity analysis of Acidovorax citrulli in China. Eur. J. Plant Pathol. 136:171-181.

45. Zhou, J. M., and Chai, J. 2008. Plant-pathogenic bacterial type III effectors subdue host responses. Curr. Opin. Microbiol. 11:179-185. 